\title{
The Xavante in perspective: anthropology and history in the study of indigenous populations
}

\author{
Rosanna Dent ${ }^{*}$
}

\author{
COIMBRA JR., C. E. A.; WELCH, J. R. (Org.). Antropologia e \\ história Xavante em perspectiva. Rio de Janeiro: Museu do \\ Índio/Funai, 2014. 216p.
}

Drawing from diverse fields of knowledge as well as a span of fifty years of scholarship, Carlos Coimbra Jr. and James R. Welch's edited volume Antropologia e história Xavante em perspectiva is a slice of very relevant history. This translation of nine carefully selected English-language publications brings together work by North American and Brazilian researchers with long experience in Central Brazil. The Xavante, auto-denominated A'uwẽ, are a Jê-speaking group with territory in the state of Mato Grosso. As the editors note in their introduction to the compilation, they are also one of the most extensively studied indigenous groups in Brazil. In 1946, the first Xavante group opted to establish formal relations with the Brazilian government. Since then, scholars from many areas of the human sciences have visited and studied Xavante communities. This compilation speaks to the depth and diversity of scholarship produced since the mid-twentieth century.

In making this series of articles available to Portuguese-speaking audiences, Coimbra and Welch have assembled a resource for a broad readership. Representing various facets of anthropological scholarship, the chapters focus on Xavante linguistics, history, social structure, human ecology and demography. As the editors readily acknowledge, the collection is not comprehensive. Rather, it represents a sampling of a large English-language literature of research conducted primarily in one Xavante Terra Indígena, Pimentel Barbosa. Produced as part of a Museu do Indio initiative to document and disseminate indigenous culture, art, and knowledge, this mix of classic and recent scholarship will serve scholars, students, and even the subjects of the studies themselves.

\footnotetext{
* Department of History and Sociology of Science, University of Pennsylvania, Philadelphia, PA, United States of America (rdent@sas.upenn.edu).
} 
Antropologia e história Xavante em perspectiva is more than a sum of its parts. The editors' thoughtful first chapter and introduction, "Os Xavante e seus etnógrafos" simultaneously situates the volume as a whole and contextualizes each article politically and temporally. As Coimbra and Welch describe each chapter, they are attentive to the professional networks and personal relationships between the scholars whose work is represented. They explain that the community of researchers who study the Xavante has evaded the common paternalistic, possessive "my tribe" syndrome suffered by some anthropologists. Rather than a territorial and competitive ethos, the field is marked by interdisciplinary, intellectually generous approaches.

This has been true ever since the first studies. The earliest contribution to the volume, the 1965 Anthropos article "Some crucial distinctions in central Brazilian ethnology" (chapter 2), was one of the first publications of Harvard anthropologist David Maybury-Lewis (1929-2007). Maybury-Lewis was both the first academic scholar to carry out an in-depth ethnographic study with the Xavante and the first social scientist to closely collaborate with a team of biomedical researchers. This particular chapter is an investigation into the origin of the Xavante as a people, and proposes relationships and timelines for the formation and migration of the Xavante in relation to other Jê-speaking groups. The fieldwork that gave rise to this research and the publications resulting from Maybury-Lewis' interdisciplinary work laid a solid foundation for future research (MAYBURY-LEWIS, 1968, 1974; NEEL et al., 1964; SALZANO; NEEL; MAYBURY-LEWIS, 1967).

Indeed, the depth of data that has built up over the years is one of the aspects of research on the Xavante that is most striking and effectively highlighted in this compilation. The biomedical and ethnographic research of the 1950 s and 1960 s provided the baseline for studies in human ecology and health by Nancy Flowers in the 1970s (chapter 4). The broader research, of which this previously unpublished chapter is a part, documented changes in child growth and mortality, nutrition, and food production practices at a moment of great political and social unrest (FLOWERS 1983; GROSS et al., 1979). In the 1990s, Santos et al. again built on Flowers' earlier research to provide diachronic perspectives on mortality and morbidity as related to socio-economic changes in food production (chapter 5, see also COIMBRA et. al., 2004). The research of the 1970 s suggested a unidirectional change toward integration into the market economy and mechanized rice farming (GROSS et al., 1979). However, the research of the 1990s documented that the Xavante of Terra Indigena Pimentel Barbosa diminished their cultivation of rice following the end of a largely unsuccessful government program. Rather than transitioning away from collecting and hunting as the government had envisioned, Xavante communities reinvigorated these practices. Their later engagement with the market economy was through cultural resources - such as dance, music, and images - rather than trade in natural resources.

Two contributions focus on issues of political consensus and mobilization. Chapter 3, a translation of historian Seth Garfield's work, foregrounds the larger political interaction of Xavante leaders and the Brazilian state. Garfield describes the fight for land that was, and 
continues to be deeply implicated in questions of sustenance, demographic decline, and subsequent demographic rebound. Laura Graham's socio-linguistic analysis of political speaking within the Xavante public sphere (chapter 7) examines discourse practices in the mature men's council. Graham argues that the collaborative construction of formal political speech through concurrent and intertwining articulation is an essential part of Xavante consensus building. This discourse style emphasizes the collective voice over the individual. Together, these two pieces provide macro- and micro-analyses of the Xavante political practices that have been essential in the face of development and disenfranchisement in Central Brazil.

A classic 1989 article by Aracy Lopes da Silva (1949-2000) (chapter 6) together with a more recent contribution by James $R$. Welch (chapter 8 ) draw readers into the intricacies of Xavante social and spiritual organization. Lopes da Silva explores naming practices, inquiring into the gendered and generative nature of the multiple names an individual receives over the course of their lifetime. In turn, Welch describes an unnamed spiritual age group system not previously documented in the ethnographic literature. Examining the interplay between the well-known secular age groups, marked by hierarchical and disciplinary relationships, and the parallel system of spiritual belonging, which involves more amicable affective ties, Welch argues that the plurality of social organization allows for contingency and flexibility. The two chapters are windows into the complexity and nuance that the Xavante's ethnographers have worked so hard to understand.

Finally, chapter 9, an article originally published by Pereira et al. in Human organization, addresses the census classifications for indigenous people in Brazil through a detailed case study of the Xavante. The research team compared IBGE Demographic Census results with an independent set of data to analyze how national census taking constructs indigenousness, and argue that this process shapes public opinion and public policy. They found that while the national census did accurately describe certain aspects of Xavante demographics such as population, age distribution, and sex ratios, in other senses it grossly mischaracterized Xavante social life, classifying multi-family households as nuclear families or categorizing them with orphanages and barracks as "collective domiciles."

This final chapter is a fine example of what a collection such as Antropologia e história Xavante em perspectiva has to offer researchers interested in critical perspectives on indigenous populations. As an interdisciplinary team of anthropologists, public health scholars, and demographers, the authors draw on ethnographic and historical research to critically examine the way that a population is measured and defined. The depth of their experience working with various Xavante communities and their knowledge of social organization fundamentally informed their analysis of the 2000 census categories and their ongoing policy recommendation for the work of the IBGE in the future. A nuanced understanding of social and cultural factors is essential for producing non-reductionist population-level studies. 
As with many of these pieces, the depth of data and long-term collaborative work by the authors allows them to formulate new kinds of questions. The Xavante were among the first groups to have diachronic studies of epidemiology, child growth, and demographics; they are one of the first indigenous populations to be critically studied in relation to the national census since the introduction of indigena as a category for cor/raça. These "firsts" are in part a result of the long history of knowledge production in Xavante communities, but they are also a result of the choices of the indigenous subjects themselves.

As the title of Coimbra and Welch's introduction suggests, the Xavante have adopted their researchers, establishing both affective and political relationships. Part of what makes the extensive, longitudinal research presented in these chapters possible is the ongoing interest of the interlocutors providing the data. Researchers' extensive work on collaborative cultural, political, and social justice projects beyond the confines of the academy (Introduction, p. 5) is further testament to the dedication of the researchers and the demands of their hosts. This interdisciplinary scholarship is not simply knowledge for knowledge's sake.

Finally, this volume and the larger Museu do Índio project that it stems from is a testament to the changing face of scholarship on indigenous populations. As Cesar Gordon notes in his preface to the book, perhaps the fastest growing audience for this kind of volume are the very people who the research documents. Making these pieces available in Portuguese is part of a longer commitment on the part of Coimbra, Welch, their colleagues, and the Museu do Índio to return the results of their research to Xavante communities.

\section{References}

COIMBRA JR., C. E. A.; FLOWERS, N. M.; SALZANO, F. M.; SANTOS, R. V. The Xavante in transition: health, ecology, and bioanthropology in central Brazil. Ann Arbor: University of Michigan Press, 2004.

FLOWERS, N. M. Forager farmers: The Xavante indians of central Brazil. Ph.D, City University of New York, USA, 1983.

GROSS, D. R.; EITAN, G.; FLOWERS, N. M.; LEOI, F. M.; RITTER, M. L.; WERNER, D. W. Ecology and acculturation among native peoples of central Brazil. Science, v. 206, n. 4422, p. 1043-50, 1979.

MAYBURY-LEWIS, D. The savage and the innocent. 2. ed. Boston: Beacon Press, 1968.

Akwẽ-Shavante society. 2. ed. Oxford: Oxford University Press, 1974.

NEEL, J. V.; SALZANO, F. M.; KEITER, F.; MAYBURY-LEWIS, D; JUNQUEIRA, P. C. C. Studies on the Xavante indians of the Brazilian Mato Grosso. American Journal of Human Genetics, v. 16, n. 1, p. 52-140, 1964.

SALZANO, F. M.; NEEL, J. V.; MAYBURY-LEWIS, D. Further studies on the Xavante indians. 1. Demographic data on two additional villages: genetic structure of the tribe. American Journal of Human Genetics, v. 19, n. 4, p. 463-89, 1967. 


\section{About the author}

Rosanna Dent is doctoral candidate, Department of the History and Sociology of Science, University of Pennsylvania (PhD expected May 2016); MA, History and Sociology of Science, University of Pennsylvania; BA with honors, Biology, Brown University.

\section{Contact address}

Department of History and Sociology of Science University of Pennsylvania Cohen Hall 303, 249 S. $36^{\text {th }}$ Street, 19104 - Philadelphia PA, USA

Received for publication in 28/10/2015 Accepted for publication in 11/06/2016 